\title{
Shear bond strength of orthodontic tubes bonded directly with composite resinreinforcement on the enamel surface
}

Resistência ao cisalhamento de tubos ortodônticos colados diretamente com reforço de resina

composta na superfície de esmalte

Resistencia al corte de los tubos de ortodoncia unidos directamente con refuerzo de resina

compuesta

Received: 11/18/2021 | Reviewed: 11/24/2021 | Accept: 11/29/2021| Published: 12/11/2021

\author{
Tainah Oliveira Rifane \\ ORCID: https://orcid.org/0000-0001-6120-1672 \\ Faculdade Paulo Picanço, Brazil \\ E-mail: tainah08@gmail.com \\ Italo Hudson Tavares Maia \\ ORCID: https://orcid.org/0000-0003-4274-115X \\ Faculdade Paulo Picanço, Brazil \\ E-mail: italohudson98@hotmail.com \\ Andressa Silva de Oliveira \\ ORCID: https://orcid.org/0000-0001-9015-844X \\ Faculdade Paulo Picanço, Brazil \\ E-mail: andressa_oliveira21@outlook.com \\ Ranyele Elis Alexandre Rodrigues \\ ORCID: https://orcid.org/0000-0001-6437-208X \\ Faculdade Paulo Picanço, Brazil \\ Email: ranylily.rr@gmail.com \\ Francisbênia Alves Silvestre \\ ORCID: https://orcid.org/0000-0001-8620-8678 \\ Faculdade Paulo Picanço, Brazil \\ Email: beninha00@hotmail.com \\ Manuela Timbó Farrapo \\ ORCID: https://orcid.org/0000-0003-4480-4214 \\ Faculdade Paulo Picanço, Brazil \\ E-mail: manuela.timbo@hotmail.com \\ Nara Juliana Custódio de Sena \\ ORCID: https://orcid.org/0000-0002-3924-477X \\ Universidade Federal do Ceará, Brazil \\ E-mail: narajuliana@gmail.com \\ Felipe Franco Marçal \\ ORCID: https://orcid.org/0000-0003-3227-9889 \\ Clínica Escola Odontologia Unichristus, Brazi \\ E-mail: felipef.marçal@gmail.com \\ Lara Ferreira Barroso \\ ORCID: https://orcid.org/0000-0001-7022-2571 \\ Faculdade Paulo Picanço, Brazil \\ Email: laraferreira2508.@gmail.com \\ Samara Tábata Cavalcante Braga Medeiros \\ ORCID: https://orcid.org/0000-0003-0650-7307 \\ Faculdade Paulo Picanço, Brazil \\ E-mail: samaratabatacavalcante@hotmail.com \\ Victor Pinheiro Feitosa \\ ORCID: https://orcid.org/0000-0001-8795-9967 \\ Faculdade Paulo Picanço, Brazil \\ E-mail: victor.feitosa@facpp.edu.br
}

\begin{abstract}
To evaluate the shear bond strength and the fracture type of orthodontic tubes bonded directly with composite resin throughout the enamel surface. 30 bovine teeth were cut into 3 slices with $5 \mathrm{~mm}$ each and embedded in PVC pipes with acrylic resin exposing the buccal face. Subsequently, the teeth were submitted to conventional bonding techniques. Natural Ortho resin was applied for direct bonding of Edgewise Standard orthodontic tubes (Morelli®) and light-cured for 20s. A different viscosity resin was chosen and light-cured for 40s to reinforce the tube surface. The samples were divided into the following groups: Orthodontic tube with direct bonding without reinforcement
\end{abstract}


(CONTROL), Tube with Natural Ortho resin + Reinforcement $(\mathrm{NO}+\mathrm{NO})$, Tube with Natural Ortho resin + Reinforcement with Flow resin (NO + FL). These were submitted to shear bond strength; immediate and 1-year aging fracture analysis after simulated through thermocycling. In the shear bond strength test, the group of orthodontic tubes that were directly bonded with Natural Ortho resin and reinforced (NO + NO) showed greater strength results after 24 hours and 1 year with values of $(p=0.0225)$ and $(p=0.0273)$. It was statistically differentto the $\mathrm{NO}+\mathrm{FL}$ and CONTROL reinforced groups. In the fracture analysis, the $\mathrm{NO}+\mathrm{NO}$ group was classified immediately as composite cohesive, and mixed failure after aging by thermocycling. The addition of a composite resin layer on the surface of the directly bonded orthodontic tube improved bond strength. The reinforcement must be carried out in regular consistency and the use of Flow resin is not indicated.

Keywords: Orthodontic tube; Direct bonding; Resin reinforcement.

\section{Resumo}

Avaliar a resistência ao cisalhamento de tubos ortodônticos de forma direta com reforço de resina composta na superfície do esmalte. Foram utilizados 30 dentes bovinos, cortados em 3 partes de $5 \mathrm{~mm}$ de altura devido. Cada parte foi embutido em canosde PVC com resina acrílica de modo que a face vestibular ficasse exposta. Aplicou-se a resina fotopolimerizada Natural Ortho para a colagem direta do tubo ortodônticos Edgewise Standart (Morelli®), após a polimerização da resina por 20 s, foi realizado o reforço em toda superfície do tubo com resina de diferente viscosidade fotopolimerizado a área por 40s. As amostras foram divididas nos seguintes grupos: Controle tubo ortodôntico com colagem direta sem reforço (CONTROLE), Tubo com resina Natural Ortho + Reforço (NO + NO), Tubo com resina Natural Ortho + Reforço com resina Flow (NO + FL) que foram destinados à resistência ao cisalhamento e análise de fratura imediata e após o envelhecimento de 1 ano simulado pela temorciclagem. No teste de cisalhamento, o grupo do tubo ortodôntico colados de forma direta com a resina Natural Ortho e reforçados (NO + NO) demonstrou melhores resultados de resistência após de 24 horas e 1 ano com valores de $(\mathrm{p}=0.0225)$ e $\mathrm{p}=0.0273$ ). Ele foi estatisticamente superior aos grupos reforçados NO + FL e CONTROL Na análise de fratura o grupo $\mathrm{NO}+\mathrm{NO}$ foi classificado no imediato como coesiva em compósito, e falha mista após envelhecimento por termociclagem. A adição de uma camada de resina composta na superfície no tubo ortodôntico colados de forma direta foi significante para melhorar a resistência de união. O reforço deve-se ser realizado na consistência regular e não é indicado o uso da resina Flow.

Palavras-chave: Tubo ortodôntico; Colagem direta; Reforço de resina.

\section{Resumen}

Evaluar la resistencia al corte y el tipo de fractura de los tubos de ortodoncia directamente con refuerzo de resina compuesta en la superficie del esmalte. Se utilizaron 30 dientes de bovino, cortados en 3 piezas de $5 \mathrm{~mm}$ de altura. Cada parte se incrustó en tubos de PVC con resina acrílica para que la cara bucal quedara al descubierto. Se aplicó resina fotopolimerizable Natural Ortho para la unión directa de tubos de ortodoncia Edgewise Standard (Morelli®) Después de la polimerización de la resina, toda la superficie del tubo se reforzó con resina de diferente viscosidad. Las muestras se dividieron en los siguientes grupos: Tubo de ortodoncia de control con unión directa sin refuerzo (CONTROL), Tubo con resina Natural Ortho + Refuerzo (NO + NO), Tubo con resina Natural Ortho + Refuerzo con resina Flow $(\mathrm{NO}+\mathrm{FL})$ que Se propusieron resistencia al cizallamiento $(n=15)$ y análisis de fractura inmediata y después de 1 año de envejecimiento. En la prueba de cizallamiento, el grupo de tubo de ortodoncia unido directamente con resina Natural Ortho y reforzado (NO + NO) mostró mejores resultados de resistencia a las 24 horas y 1 año con valores de $(\mathrm{p}=0.0625 \mathrm{yp}=0.0703)$. Fue estadísticamente superior a los grupos reforzados con $\mathrm{NO}+$ FLy CONTROL En el análisis de fracturas, el grupo NO + NO se clasificó inmediatamente como cohesivo en composite, y falla errónea después del envejecimiento por termociclado. La adición de una capa de resina compuesta en la superficie del tubo de ortodoncia directamente adherido fue importante para mejorar la resistencia de la unión. El refuerzo debe realizarse con consistencia regular y no está indicado el uso de resina Flow.

Palabras clave: Tubo de ortodoncia; Vinculación directa; Refuerzo de Resina.

\section{Introduction}

The success of a fixed orthodontic appliance depends on the bonding and correct positioning of its components, which results in an effective force transmission system. Thus providing an orderly and planned tooth movement (Baer et al., 1964; Oeiras et al., 2016). During the planning of fixed appliance and orthodontic mechanics, bands are basic elements, classically indicated for the molar region in which they are welded to orthodontic accessories (Limberger et al., 2011).

However, studies show that the use of cemented orthodontic bands on the tooth may cause damage to oral tissues as well as metabolic activity, changing the amount and pathogenicity of oral microbiota, which may cause the development of caries. It happens due to the balance change of demineralization and remineralization in this area. Moreover, the activation of 
inflammatory mechanisms culminates in hyperplasia in the surrounding gingival tissue (Baer et al., 1964; Sadowsky et al.,

1981; et al., 2011; et al., 2012). The study of direct bonding tubes that have advantages such as shorter operative time and lower periodontal risk is growing. (Nazir et al., 2011)

The use of orthodontic tubes for direct bonding for treatment with fixed appliances becomes possible due to the improvement of clinical techniques and evolution of dental materials. (Flores-mir et al., 2011). Thus, the bases were modified and changed from smooth structures to a mesh with grooves, which facilitated the overlapping of material, promoting adequate and higher bond strength to the tooth structure (Sharma, T et al., 2004;Perumal et al., 2004;Perumal et al., 2004). al., 2010). It craves to overcome clinical deficiencies, reducing the occurrences caused by orthodontic bands (Pinzan-Vercelino et al., 2011).

According to Tortamano et al (2016), the use of molar tubes glued directly to the tooth surface is increasing.

However, this technique still has flaws regarding its clinical survival, such as adequate resistance to withstand the forces promoted by orthodontic movement and areas with great masticatory effort such as lower posterior teeth (Millet et al., 2017). A new alternative to increase the strength of direct bonding is to add resin reinforcement to the surface of the orthodontic tube in order to increase the efficiency of traditional bonding for teeth subjected to greater masticatory impacts. This management aims to reduce the deficiency of the aforementioned technique, distributing the forces and facilitating cleaning (Dalanezi et al., 2011; Flores-Mir et al., 2011).

In addition, this method may be effective to increase the quality of bonding with greater contact between the tooth and tube. Although there is no sufficient report of resin reinforcement related to orthodontics tubes and its possible benefits for bonding to enamel. Therefore, the aim of this study is to evaluate the shear bond strength of tubes orthodontics directly bonded with resin reinforcement in different viscosities. The null hypothesis is that the reinforcement of composite resin to the orthodontic tube in its conventional or fluid form there will be no difference in mechanical shear strength.

\section{Methodology}

\section{Preparation of specimens}

Thirty healthy bovine teeth, obtained from a private establishment, were selected. Roots were sectioned at cementoenamel junction, cleaned and preserved in $0.1 \%$ thymol in a refrigerated environment. Subsequently, sectioned in a cutter (Isomet 1000, Buehler, Lake Bluff, IL) and divided into three slices, with a minimum height of $5 \mathrm{~mm}$ measured with a digital caliper (Digimess, São Paulo, Brazil). Each tooth was embedded in rigid 4mm PVC pipes with acrylic resin to expose the buccal surface only. The use of these teeth in the research was adopted due to their similarity to human enamel. The acrylicresin was established with a combination of Self Curing Acrylic Pink Powder (JET, São Paulo, Brazil) and Self Curing AcrylicLiquid (JET, São Paulo, Brazil). The bovine tooth was inserted in the plastic stage.

Prophylaxis with pumice stone was performed for 30 seconds in all samples, changing the brush every five polishes. Then, the enamel was etched with $37 \%$ phosphoric acid Condac (FGM, Joinville, Brazil) for 30 seconds and washed with water for 60 seconds and air-dried from the triple syringe for 15 seconds. The fractures were classified as adhesive, cohesive in composite or dentin and mixed. Surface drying was performed with moisture-free air jets for 15 seconds. Subsequently, the Alpha Bond (DFL, Rio de Janeiro, Brazil) was applied vigorously for 20 seconds with a Carvibrush microbrush (FGM, Joinville, Brazil) according to the manufacturer's instructions, light cured for 20 seconds by LEDLUX II (Ortus, Goiânia, Brazil) with a luminous intensity of 1,400Mw/CM2 being controlled by a radiometer (Godard et al., 2017).

Natural Ortho light-cured resin was applied with tube clamps (Morelli®, Sorocaba, Brazil). The tubes used were: simple 018 Edgewise Standard (Morelli®, Sorocaba, Brazil), fixed on the buccal surface of the bovine teeth and pressed with aforce of $2 \mathrm{gf}$ (gram force). The removal of excesses was carriegd out with an exploratory probe number 5 (Duflex, SS White, 
Brazil). After resin polymerization, the groups were reinforced with Natural Ortho Resin or Flow-Opallis Resin (FGM, Joinville, Brazil) on all tube surfaces and light cured for 40 seconds. All sets were stored in distilled water at $37{ }^{\circ} \mathrm{C}$ for 24 hours for immediate testing and thermocycling. In the group with resin flow, the reinforcement was applied through a syringe.

Thus, the samples were randomly divided into the following groups: Control with tube directly bonded without reinforcement (Control), Tube with Natural Ortho resin + Reinforcement $(\mathrm{NO}+\mathrm{NO})$, Tube with Natural Ortho resin + Reinforcement with Flow resin (NO+FL). After thermocycling: Control (Control 1y), Tube with Natural Ortho resin + Reinforcement (NO + NO 1y), Tube with Natural Ortho resin + Reinforcement with Resin Flow (NO + FL 1y).

\section{Thermocycling}

1000 cycles in distilled water was performed in a thermocycling machine (TC45, Peter Huber Kältemaschinenbau $\mathrm{AG}$, Germany) at temperatures of $5^{\circ} \mathrm{C}\left( \pm 2^{\circ} \mathrm{C}\right)$ and $55^{\circ} \mathrm{C}\left( \pm 2^{\circ} \mathrm{C}\right)$. Each cycle was performed for 20 seconds, with an interval of 5 to 10 seconds. The samples that were not submitted to the process were stored in refrigeration at $8^{\circ} \mathrm{C}$.

\section{Shear bond strength}

The shear bond strength test was performed on EMIC Universal Testing machine (DL 2000, São José dos Pinhais, Brazil), with a load cell of $100 \mathrm{Kgf}$ at a speed of $0.5 \mathrm{~mm} / \mathrm{min}$. The height, width and length measurements of each orthodontic tube were taken with the help of a caliper before the tests. The strength values were measured in Newtons (N) and MegaPascal (MPa). The mechanical shear bond strength test was performed following the cervical occluded direction, with the chisel positioned at the tooth-tube interface forming an angle of $90^{\circ}$ (Figure 5).

\section{Fracture Pattern Analysis}

The failure mode of each fractured stick was analyzed using a stereomicroscope at 100x magnification (Olympus SZ 40-50, Tokyo, Japan). The fractures were classified as adhesive, cohesive in composite or dentin and mixed in composite or cohesive in dentin. Bond (when the failure occurred in the bonding system), cohesive in resin (when the fracture occurred in the composite resin), cohesive in enamel/dentin (when the fracture occurred in the dental substrate) and mixed (when the analysis of both fragments showed the presence of bond).

\section{Statistical analysis}

Data were organized in Microsoft Office Excel 2016 spreadsheets (Microsoft, Washington, USA) and distributed in Tables and graphs. Subsequently, the data were transferred to the statistical program Stat 32 with analysis of variance ANOVAand Tukey's complementary test with confidence interval at $99 \%$ and statistical significance established at $\mathrm{p}<0.05$.

\section{Results and Discussion}

The shear bond strength test of orthodontic tubes bonded directly is shown in Figure 1. The NO + NO group showed satisfactory results of immediate and aging. It was statistically different compared to the Control group. The Control group showed lower bond strength compared to NO + FL, while this group obtained strength values from an intermediate bond with statistical difference. The $\mathrm{NO}+\mathrm{NO}$ and $\mathrm{NO}+\mathrm{FL}$ group were statistically differentcompared to the Control group.

The fracture pattern of the $\mathrm{NO}+\mathrm{NO}$ and $\mathrm{NO}+\mathrm{FL}$ groups were classified as cohesive composite within 24 hours. After aging by thermocycling, it was classified as mixed failure. The Control group had predominantly a high percentage of bond failure after $24 \mathrm{~h}$ and mixed after aging time. 
Figure 1.
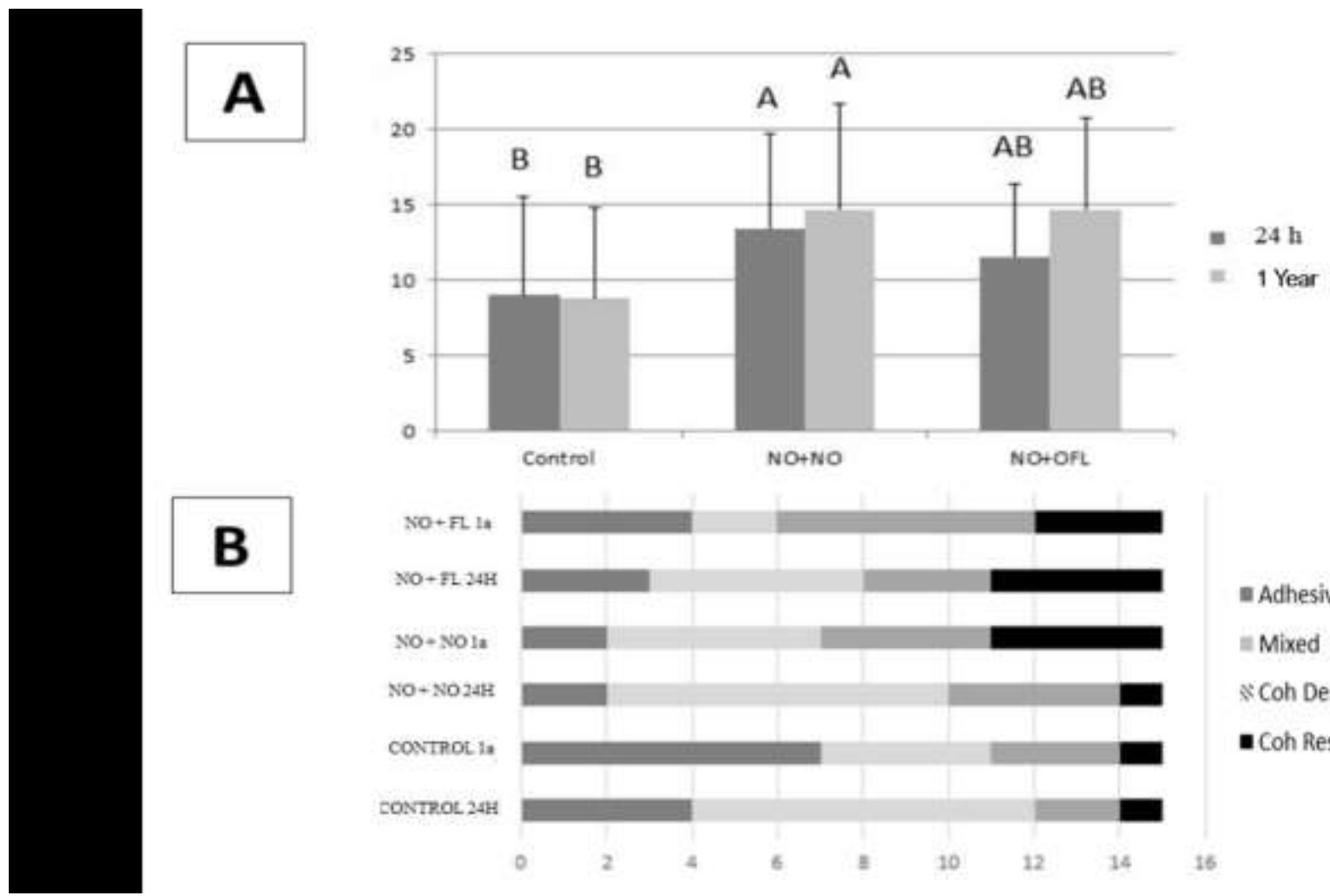

Adhesive

Mixed

\& Coh Dentin

- Coh Resin

Source: Authors.

\section{Discussion}

Since the additional layer of composite resin on the orthodontic tube surface may create an contact area between the tooth and the orthodontic tube, this study was based on comparing two composite resins in their fluid form (Opallis) and conventional orthodontic composite resin (Natural Ortho) and its bonding to enamel. The $\mathrm{NO}+\mathrm{NO}$ group demonstrated greater shear bond strength test values. Thus, the null hypothesis was rejected, as the addition of composite resin conventional proved to be effective in resisting shear when compared to tubes without this method of reinforcement.

The area where the additional composite resin layer was applied may be easily sanitized, even if bonding materials present roughness in its structure (Figure 3). This fact is likely controlled in periodic appointments with a dentist. It's crucial not to hinder the passage of orthodontic wire for adequate tooth movement, as shown in Figure 4 (Wadia et al., 2019). In addition to being located far from the marginal gingiva, it does not damage periodontal tissues such as orthodontic bands (Millett et al., 2017). This method offers resistance to the forces of orthodontic and masticatory movement in view of the results obtained in this study, the orthodontic resins are shown in Figure 2 (Pg Murray et al., 2012). In the shear bond strength test, the $\mathrm{NO}+\mathrm{NO}$ group obtained greater bond strength values with statistical difference compared to the Control group and the NO + FL group of $(\mathrm{p}=0.0225)$ and $(\mathrm{p}=0.0273)$. The reinforcement with fluid resin showed intermediate values of bond strength, increasing its result after thermocycling. 
Research, Society and Development, v. 10, n. 16, e195101623481, 2021

(CC BY 4.0) | ISSN 2525-3409 | DOI: http://dx.doi.org/10.33448/rsd-v10i16.23481

\section{Figure 2.}
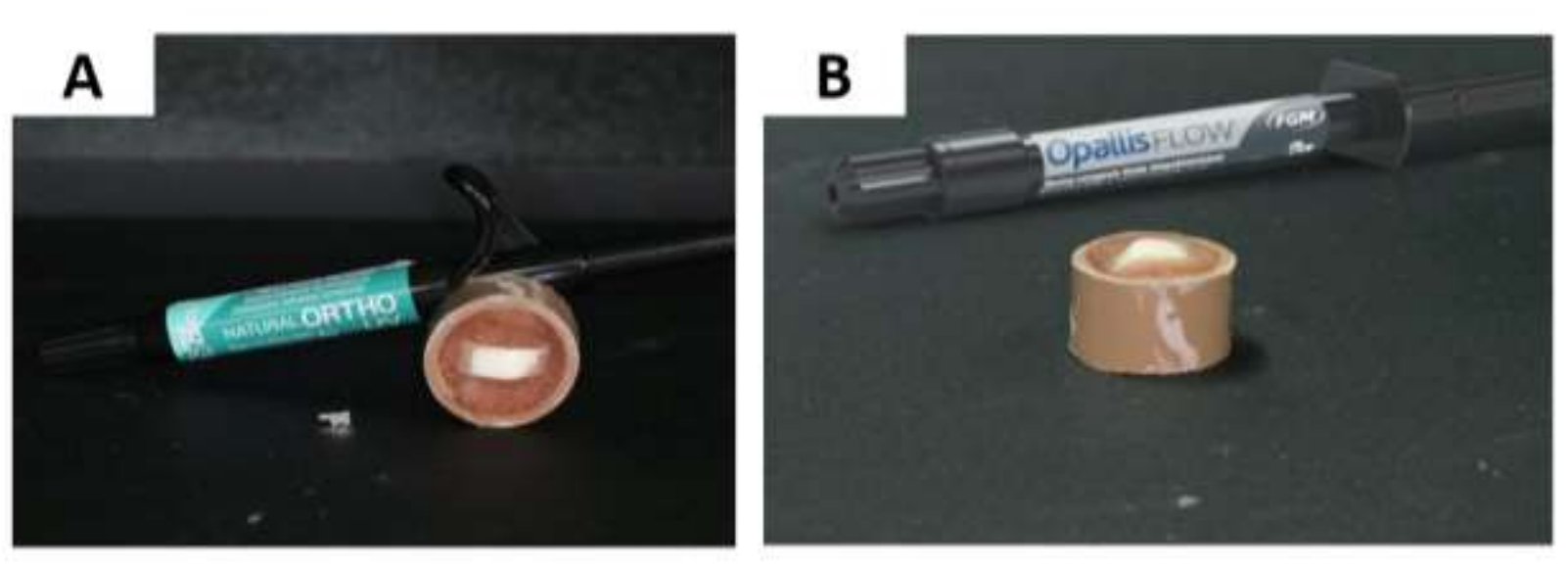

Source: Authors.

Figure 3.

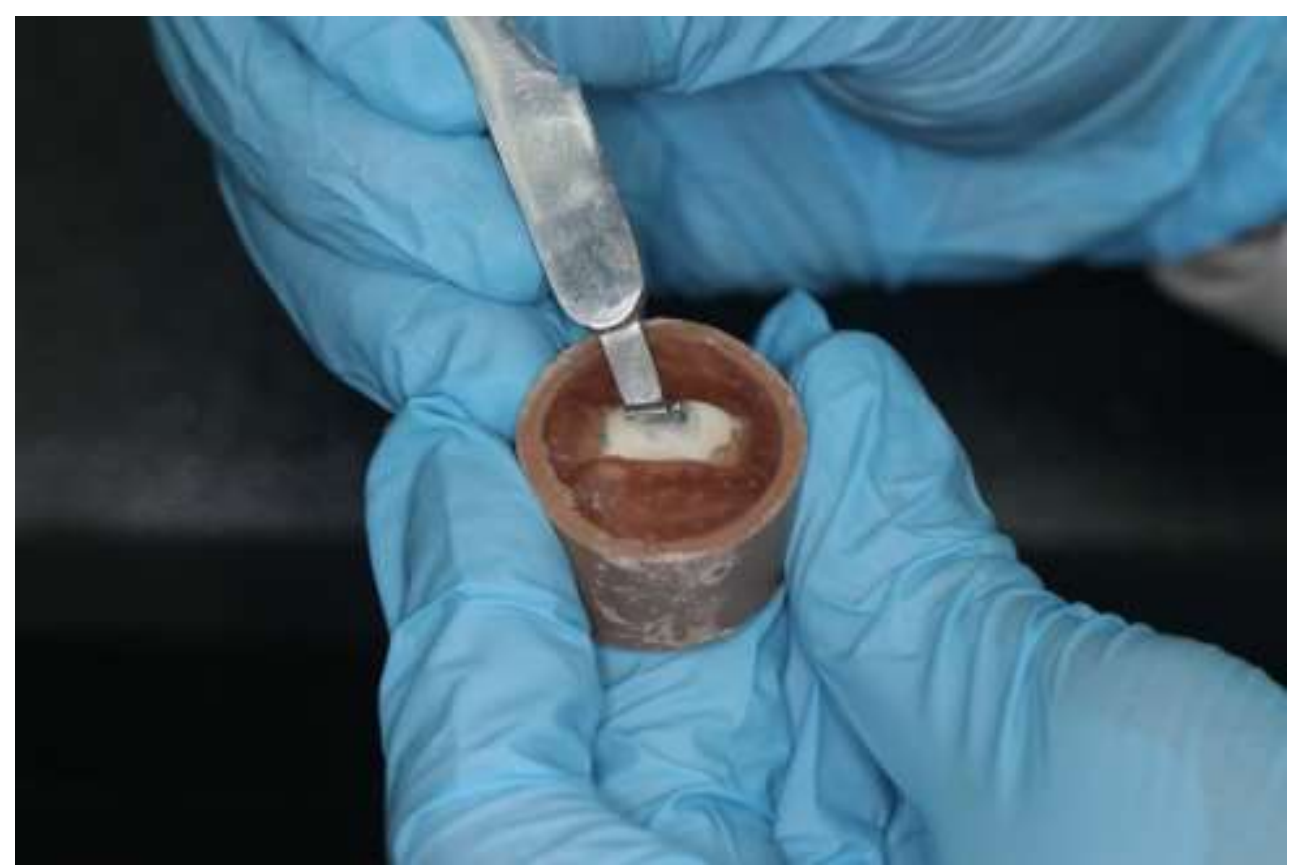

Source: Authors.

Figure 4.
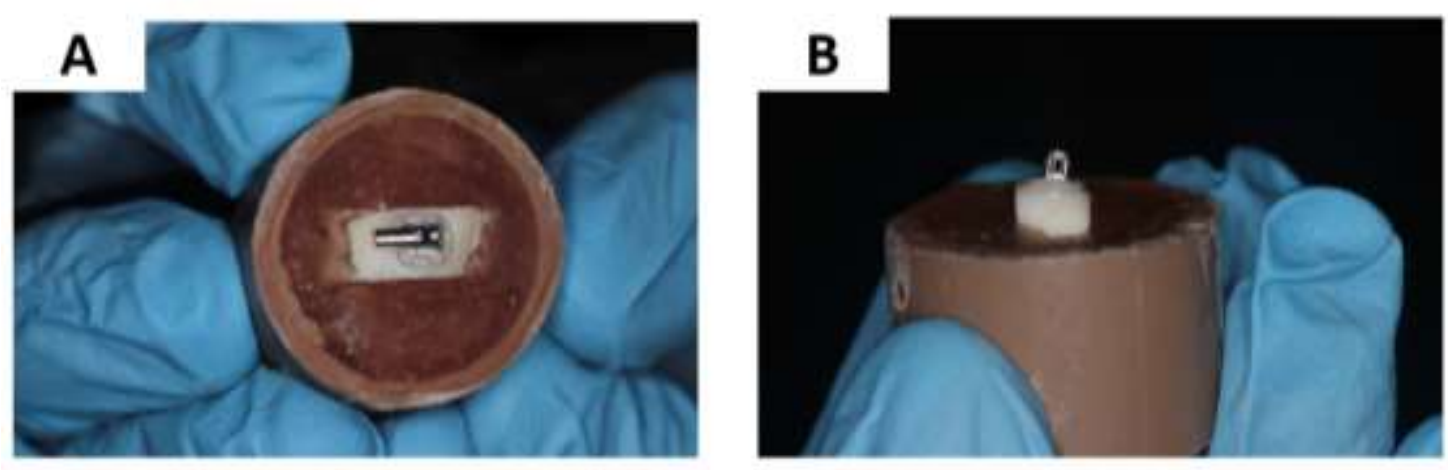

Source: Authors. 


\section{Figure 5.}
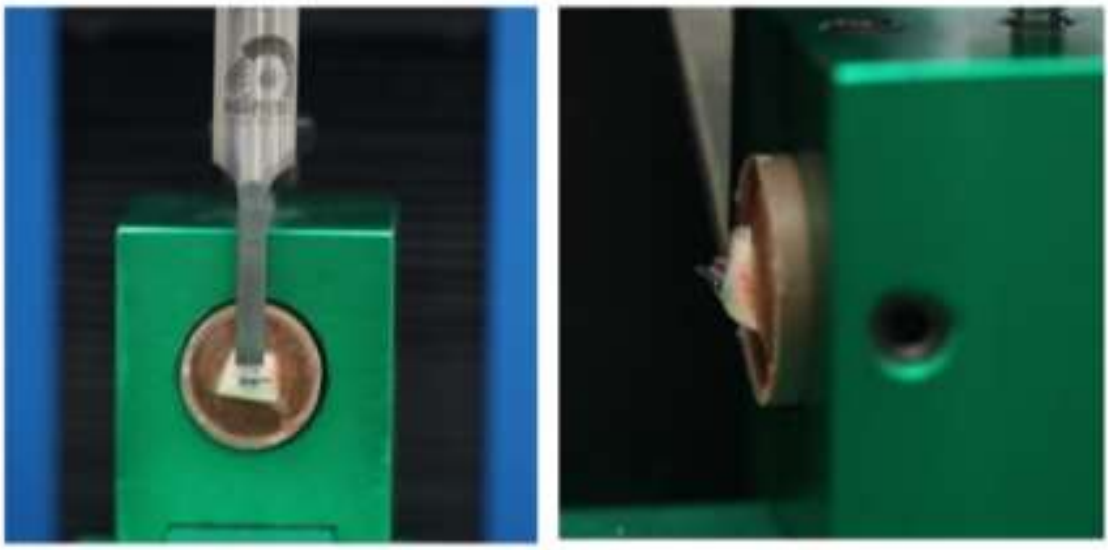

Source: Authors.

Thus, these results may occur due to the different composition between composite resin in its conventional and fluid form. In its regular form, it has more viscous monomers of high molecular weight, such as BISGMA (bisphenol glycidyl methacrylate), with particle loading up to $85 \%$. The fluid composite resin (flow) has fluid monomers with lower molecular weight and less amount of charge particles, reaching up to 70\%. It directly influences the improvement of physical and mechanical properties which determine its performance and clinical indications. The filler particles reduce water absorption, reduce polymerization shrinkage, and improve stress absorption. Thus, the difference between the materials may be a fact that explains great results of the $\mathrm{NO}+\mathrm{NO}$ group.

Corroborating this result, the analysis of fracture pattern of the $\mathrm{NO}+\mathrm{NO}$ and $\mathrm{NO}+\mathrm{FL}$ group was classified as cohesive in composite and mixed after 1 year, with less bonding failure when compared to the rest of the groups. The control group showed a higher percentage of bonding failure after aging, since this group was not reinforced with composite resin, clinically affecting the progress of treatment with fixed appliances. This failure would be a delaying factor in planning (Keim et al., 2010). However, for clinical use of this reinforcement method, it is recommended to quantify the bonding material to avoid the interference with the occlusal relation between the upper and lower molars.

To simulate oral aging, thermocycling was adopted for the study. It's an in vitro process that submits the restoration and the tooth to extreme temperatures compatible with those found in the oral environment (Rossomando et al., 1995). It simulates the aging of materials, which may influence the integrity of the restorative material and the cementing agent (Faria et al., 2004). After thermocycling, there were differences in thermal expansion between the bond, orthodontic attachment and enamel. The temperature change leads to weakness within the bond, affecting the bond and strength of the material. It simulates the clinical situation that these materials will be submitted to in the oral cavity (Liu et al., 2018). Thus, the control group had lower bond strength values when compared to the other two groups, being statistically different.

Pandis et al evaluated tubes bonded directly to molars (in vivo). It was found that the first failure was after 23 months (20 to 26 months). Therefore, in this study, the simulation time for 1 year of aging was adopted, approaching the analyzes already reported in the literature. Furthermore, thermocycling may cause microscopic expansion and chemical degradation of the materials used (Pandis et al., 2005; Purmal et al., 2010). It was noted that thermocycled compounds absorb a superior amount of water when compared to samples that were not submitted to this procedure (Morresi et al., 2014). Thus, it was considered as the reason for the control group not to obtain significant results of shear bond strength after aging. And after thermocycling, the NO + FL group managed to increase its bond value, being statistically lower than the NO + NO group.

Therefore, this alternative of reinforcement with composite resin in its conventional Natural Ortho form may be 
effective, as it has been shown to increase the quality of direct bonding of orthodontic tubes to enamel. It is necessary more studies focused on the area, once the technique performance depends on the proper selection of material

\section{Conclusion}

The reinforcement of Natural Ortho composite resin to direct bond tube is a promising method to increase bond and strength of these devices to enamel. Thus, future clinical studies focused on this subject are needed to assess its applicability and effectiveness.

\section{References}

Ahmed, T., Rahman, N. A., \& Alam, M. K. (2018). Assessment of in vivo bond strength studies of the orthodontic bracket-adhesive system: A systematic review. European journal of dentistry, 12(4), 602-609.

Baer P. N., \& Cocarro J. Gingival Enlargement Coincident With Orthodontic Therapy. J. Periodontol. 35:436-439. Al-Anezi S. A. (2015). The effect of orthodontic bands or tubes upon periodontal status during the initial phase of orthodontic treatment. The Saudi dental journal, 27(3), 120-124.

Vercelino, C. R. M. P., Pinzan. A., Gurgel, J. A., Bramante, F. S., \& Pinzan, L. M, (2011) In vitro study of shear bond strength in direct bonding of orthodontic molar tubes. Dental Press J Orthod.16(3):60.e1-8.

Faria, R., Leite, F. P. P., Bottino, M. A., Araújo Jej, D. E. Efeito Da Termociclagem Sobre A Resistência De União Entre Uma Cerâmica E Um Cimento Resinoso.PCL 2004; 6(34):576-81.

D'Amario, M., Campidoglio, M., Morresi, A. L., Luciani, L., Marchetti, E., \& Baldi, M. (2010). Effect of thermocycling on the bond strength between dualcured resin cements and zirconium-oxide ceramics. Journal of oral science, 52(3), 425-430.

Flores-Mir C. (2011). Bonded molar tubes associated with higher failure rate than molar bands. Evidence-based dentistry, $12(3), 84$.

Godard, M., Deuve, B., Lopez, I., Hippolyte, M. P., \& Barthélemi, S. (2017). Shear bond strength of two 2-step etch-and-rinse adhesives when bonding ceramic brackets to bovine enamel. International orthodontics, 15(3), 388-404. https://doi.org/10.1016/j.ortho.2017.06.003

Keim, R. G., Gottlieb, E. L., Nelson, A. H., \& Vogels, D. S., 3rd (2008). 2008 JCO Study of Orthodontic Diagnosis and Treatment Procedures. Part 2: breakdowns of selected variables. Journal of clinical orthodontics: JCO, 42(12), 699-727.

Limberger, K. M., Westphalen, G. H., Menezes, L. M., \& Medina-Silva, R. (2011). Cytotoxicity of orthodontic materials assessed by survival tests in Saccharomyces cerevisiae. Dental materials: official publication of the Academy of Dental Materials, 27(5), e81-e86. https://doi.org/10.1016/j.dental.2011.01.001

Liu, Y. N., Wang, L. K., Liu, S. S., Li, W. F., \& Wang, H. F. (2018). Zhonghua yi xue za zhi, 98(28), 2275-2278.

Millett, D. T., Glenny, A. M., Mattick, R. C., Hickman, J., \& Mandall, N. A. (2016). Adhesives for fixed orthodontic bands. The Cochrane database of systematic reviews, 10(10), CD004485.

Millett, D. T., Mandall, N. A., Mattick, R. C., Hickman, J., \& Glenny, A. M. (2017). Adhesives for bonded molar tubes during fixed brace treatment. The Cochrane database of systematic reviews, 2(2), CD008236. https://doi.org/10.1002/14651858.CD008236.pub3

Morresi, A. L., D’Amaro, M, Capogreco, M, Gatto R, Marzo G, D'Arcangelo C, et al, Thermal cycling for restorative materials: Does a standardized protocol exist in laboratory testing? A literature review. Journal of the mechanical behavior of biomedical materials.2014;29: 295-308.

Murray, P. G., Millett, D. T., \& Cronin, M. Bonded molar tubes: a survey of their use by specialist orthodontists. Journal Orthodontist. 2012 Jun;39(2):12935. 10.1179/1465312512Z.00000000016.

Nazir, M., Walsh, T., Mandall, N. A., Matthew, S., Fox, D. Banding versus bonding of first permanent molars: a multi-centre randomized controlled trial. J Orthod. 2011 Jun;38(2):81-9. 10.1179/14653121141308.

Oeiras, V. J., Silva, V. A., Azevedo, L. A., Lobato, V. S., \& Normando, D. (2016). Survival analysis of banding and bonding molar tubes in adult patients over a 12-month period: a split-mouth randomized clinical trial. Brazilian oral research, 30(1), e136.

Pandis, N., Christensen, L., \& Eliades, T. (2005). Long-term clinical failure rate of molar tubes bonded with a self-etching primer. The Angle orthodontist, 75(6), 1000-1002.

Pandis, N., Polychronopoulou, A., \& Eliades, T. (2006). A comparative assessment of the failure rate of molar tubes bonded with a self-etching primer and conventional acid-etching. World journal of orthodontics, 7(1), 41-44. 
Research, Society and Development, v. 10, n. 16, e195101623481, 2021

(CC BY 4.0) | ISSN 2525-3409 | DOI: http://dx.doi.org/10.33448/rsd-v10i16.23481

Pinzan-Vercelino, C. R., Pinzan, A., Gurgel, A., Bramante, F. S., \& Pinzan, L.M. (2011). In-vitro evaluation of an alternative method to bond molar tubes. J App Oral Sci, 19:41-6.

Purmal, K., \& Sukumaran, P. (2010). Shear bond strengths of buccal tubes. Australian orthodontic journal, 26(2), 184-188.

Sadowsky, C, \& BeGole, E. A. Long-term effects of orthodontic treatment on periodontal health. Am J Orthod. 1981 Aug;80(2):156-72. 10.1016/00029416(81)90216-5.

Sharma, T., Phull, T. S., Rana, T., \& Kumar, V. (2014). Expressly fabricated molar tube bases: enhanced adhesion. Journal of clinical and diagnostic research : JCDR, 8(6), ZD16-ZD18

Wadia, R. (2019). Composite resin roughness anda biofilms. British Dental Journal, Dec; 227 (12): 104.

Zachrisson B. U., \& Zachrisson S. Caries Incidence And Oral Hygiene During Orthodontic Treatment. Scand. J. Dent. Res. 79:394-401.

Walsh, L. J., \& Healey, D. L. (2019). Prevention and caries risk management in teenage and orthodontic patients. Australian dental journal, 64 Suppl 1, S37S45. 